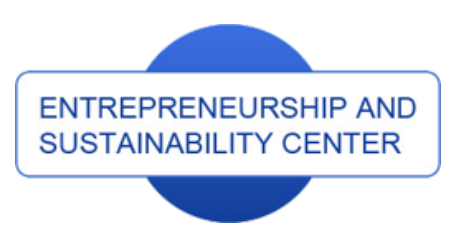

Publisher

http://jssidoi.org/esc/home

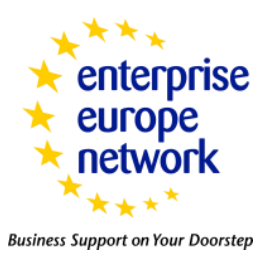

CASPA

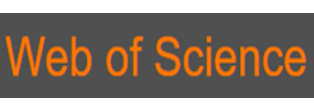

Clarivate

\title{
FLEXIBLE FORMS OF EMPLOYMENT, AN OPPORTUNITY OR A CURSE FOR THE MODERN ECONOMY? CASE STUDY: BANKS IN POLAND
}

\author{
Jerzy Kaźmierczyk ${ }^{1}$, Aleksandra Chinalska² \\ ${ }^{1,2}$ Poznan University of Economics and Business, al. Niepodległości 10, 61-875 Poznań (Poland) \\ ${ }^{1}$ Tyumen State University, 6 Volodarskogo St., 625003 Tyumen, (Russia) \\ E-mails: ${ }^{1}$ jerzy.kazmierczyk@ue.poznan.pl ; $^{2}$ aleksandrachinalska@vp.pl
}

Received 15 June 2018; accepted 2 October 2018; published 30 September 2018

\begin{abstract}
The presented topic is of utmost importance due to the consequences that the implementation of atypical forms of employment has for all labour market actors. Sometimes employees decide on such forms of employment due to the pressure from employers who see it as a chance to optimize the costs. The conducted study confirmed that flexible forms of employment are more common among young people, who are at the beginning of their professional career, than among workers with seniority. The flexible forms of employment are also less frequent among managerial staff. The discussion is supported by empirical research conducted on a sample of 1,920 bank employees in Poland. This study is the first one that investigates the flexible forms of employment on a big sample of Polish bank employees and show the character of Polish bankers.
\end{abstract}

Keywords: flexible forms of employment; flexible staffing arrangements; atypical employment; alternative work arrangements; flexibility; flexicurity; banking

Reference to this paper should be made as follows: Kaźmierczyk, J.; Chinalska, A. 2018. Flexible forms of employment, an opportunity or a curse for the modern economy? Case study: banks in Poland, Entrepreneurship and Sustainability Issues 6(2): 782-798. http://doi.org/10.9770/jesi.2018.6.2(21)

JEL Classifications: J4, J8, J81, M5

\section{Introduction}

Recent years have seen rapid economic, demographic and social changes on both the global and Polish market (Voronov, Lavrinenko and Stashane 2014; Romashkina and Andrianova 2007; Bondaryeva, Kravchenko and Mieshkov 2015; Garbat 2018). Companies need to exercise more flexibility and adapt to the changes faster (Vanhercke et al. 2014). It has resulted in a number of job opportunities based on forms other than the traditional employment contract. This diversity is dictated by the need to adapt to the new conditions, skills and expectations, both on the part of employers and employees. 


\section{The International Journal}

ENTREPRENEURSHIP AND SUSTAINABILITY ISSUES

ISSN 2345-0282 (online) http://jssidoi.org/jesi/

2018 Volume 6 Number 2 (December)

http://doi.org/10.9770/jesi.2018.6.2(21)

Some authors point out that one should look at flexible forms of employment through the prism of particular sectors of the economy (Storey et al. 2002). This allows one to see their specific character. Some sectors are adapting to flexible employment (Süß and Kleiner 2007; Schmidt 2011). According to research by Ch. Pfeifer (2005), one of such sectors is services, and especially banking. It is also one of the fastest growing sectors of the economies in Central and Eastern Europe (Kaźmierczyk 2015, Davydenko, Kaźmierczyk, Romashkina, Żelichowska, 2017). Banks often introduce new technological solutions and know-how faster than other businesses.

In addition, most banks operating in Poland belong to Western investors and that should encourage rapid implementation of the organizational and management tools from the more developed countries. Therefore, banks in Poland are expected to promote flexible forms of employment. This is accompanied by social and demographic changes, such as sharp decrease in the birthrate, the increase in enrolment, popularization and simultaneous decline in the quality of tertiary education. All things considered, the flexible forms of employment may be both an opportunity or a threat for young workers (Heyes 2011). On the other hand, the rapid development of the banking sector as a leader in introducing new solutions (also organizational ones) favours banks as the subject of study of flexible forms of employment. Flexible forms of employment in Polish banks have not so far been analyzed precisely. This study is the first that investigates the differences in flexible forms of employment that was carried out on a sample of Polish bank employees and took into account their age, level of education, work experience and the size of a bank's locality.

The main aim of this paper is to assess the popularity of flexible forms of employment in banks and compare its levels in different social groups. The two main theses propounded in this paper are that flexible forms of employment are more common among young people at the beginning of their professional career than among workers with seniority, and that flexible forms of employment are less frequent among managerial staff.

To accomplish the research aim the authors used source literature in English, German, Polish and Russian on economics, human resource management, sociology, banking and industrial and organizational psychology (The ACM Digital Library, EBSCO, Emerald, BazEkon, ProQuest). A survey of nearly 2,000 bank employees in Poland was also carried out.

This article consists of five main sections. The introduction is followed by a [general] review of the issue of employment flexibility and various forms of flexible employment and section three presents the data sources and the research methods employed. In section four, the findings are presented to be then followed by conclusions.

\section{Literature review}

The great popularity of flexible forms of employment in Europe was researched by: Jahn, Riphahn and Schnabel (2012), Storey et al. (2002), Süß and Kleiner (2007), Jasarevic (2012). In Poland, opinions on the popularity of flexible forms of employment are divided. Some authors point to the popularity of flexible forms of employment (Węgrzyn 2009). Others argue that traditional forms of employment are still dominant in Poland (Kalinowska 2008). The popularity of temporary employment in Europe ranges from 5\% (the Baltic States and Romania), to $23 \%$ (in Spain) and even over 25\% in Poland. Poland takes the first places in the ranking of temporary employment growth among Eastern European countries (International Labour Office 2016, p. 52, 56).

One of the groups that may be particularly exposed to continuous and forced work within flexible forms of employment are young people. They occupy a special position on the labour market (Andrzejczak 2014; Paszkowicz 2009; Davydenko 2004). Poland, as a consequence of the reform of the education system, has witnessed a shift towards the preparation for work on the level of higher education. There are still a lot of 
The International Journal

ENTREPRENEURSHIP AND SUSTAINABILITY ISSUES

ISSN 2345-0282 (online) http://jssidoi.org/jesi/

2018 Volume 6 Number 2 (December)

http://doi.org/10.9770/jesi.2018.6.2(21)

universities whose graduates find it difficult to find employment (especially in the area of economics and management). The labour market is unable to absorb all the graduates (Andrzejczak 2015). For this highly digitalized group the Internet is a natural environment (Barska and Wojciech, 2014). According to a study by Barska and Wojciech, in 2025 c. $75 \%$ of employees around the world will be represented by the so called millenials, i.e. people aged between 18 and 34, lazy, spoilt, impatient and heavily committed to the Internet. According to Twaronite, this group will place a high value on the flexibility of employment (2015). On the one hand, young people are "...the most tractable" (Grzeszczyk 2003, p. 68) and they are probably ready to be employed within the framework of flexible forms of employment (Shelest 2015; Shelest 2016). Moreover, younger employees are less exposed to negative organizational commitment and turnover intention attributable to job insecurity (Cheng and Chan, 2008). In turn, it is the new generation that will have an ever-growing impact on the labour market. Therefore employers, when planning their businesses' future and employment structure, will have to take into account their characteristics.

Flexible forms of employment are sometimes abused. They are often used as a cost-reducing tool (International Labour Office 2016, p. 57; Eurofound 2015; Jahn et al. 2012), while at the same time reducing worker safety. Therefore, in some countries, including Poland, they have come to be known as "junk contracts", which clearly reflects their perception by the general society (Bak-Grabowska and Jagoda 2015). This term reflects the social sense of the flexible forms of employment. Work under "junk contracts" is perceived as unstable and less paid. Regardless of the positive or negative characteristics of the flexible forms of employment, the constant emergence of new forms of employment aimed at increased flexibility can be observed (especially in the transition countries).

With such rapid changes in the economy, many people find it hard to distinguish and comprehend the general principles of the alternative forms of employment. Even the names themselves may be vague and confusing, for instance: outsourcing, staff leasing or job sharing. Despite the wide and easy access to information, many people, especially the elderly, find it difficult to distinguish between the newly-occurred unusual forms of employment. The respective rights and responsibilities that arise from them are also hardly comprehensible. It can be presumed that these forms of employment can provide certain opportunities to both the elderly and the young who are willing to take up any work.

Flexibility, in general, means versatility and ability to adapt easily to new conditions. This also pertains to the labour market where it means something completely different for both parties, employers and employees. For the former group, flexibility may refer to the necessity to adjust in many areas of one's business, such as production intensity, market competition and demand (Soniewicki 2015). Employees, on the other hand, may view flexibility as a need for lifelong learning, upskill or even changing qualifications.

With regard to the labour market, flexibility can be defined as the ability to adapt to the new market conditions, as well as changes in technology and information (Wyrwa and Piątyszek-Pych 2012). First of all, attention should be drawn to such aspects as (Kalinowska et al. 2014):

- employment flexibility, which gives entrepreneurs the opportunity to match the structure of the employees to the actual demand and changes in the volume of production and services,

- functional flexibility, allowing employees to perform many tasks in multiple positions; this is connected with multi-profile qualifications and skill diversification of employees,

- financial flexibility, that represents the variability of wages,

- flexibility of working time, offering atypical forms of working time arrangement, depending on the prevailing economic situation on the market, as well as the capacity of the company,

- spatial flexibility, that represents the freedom of choice of a locality where the assigned work will be performed. 
The concept of flexible forms of employment (or flexible work arrangements) is not easy to define. Difficulties in defining atypical forms of employment were noted by Drela (2013), Süß and Kleiner (2007). The term "alternative forms of employment" is commonly used to describe types of employment relationship which are different in form. This way of thinking has been adapted by Salikova (2012). Therefore, if such alternative forms of employment differ from the traditional ones, one can be tempted to declare that they are in contrast to the typical employment relationship (Burroni and Keune 2011). It is described by, for example, contract length being other than for an indefinite period, only part-time openings, flexible hours of work, places of work other than the head office and lack of constant supervision on the part of the employer. Banks' employment flexibility can be demonstrated by the ease with which employees are dismissed during depression, particularly in the time of economic crises. In many countries of the European Union, flexible forms of employment were more popular after the crisis (International Labour Office 2016). The Polish economy has gently suffered the last crisis. There has been no decline in GDP and the banking sector is constantly growing. Unfortunately, the collected data is not suited to assess the dynamics of flexible forms of employment under the influence of the business cycle.

Economic growth is accompanied by increased competition between companies. The importance of productivity and efficiency results in reduced costs, for example employment-related ones. Flexible forms of employment enable to reduce operating costs, and sometimes protect workers against unemployment (Wilthagen 1998). Moreover, aging societies and cultural transformations, such as changes in women and men's roles in the family, or an increase in the number of single parents raising children, contribute to the emergence of atypical forms of employment (European Commission 2007). A tendency to relax these regulations in a big part of OECD countries is observed (OECD 2013). These all intensify the development of flexible security.

Classification of flexible forms of employment can be accomplished in several ways, using different criteria. Considering degrees of flexibility, we can distinguish different flexible forms of employment, such as (Kalinowska et al. 2014):

- very flexible (contract of mandate, contract for specific work, management contract, teleworking, outsourcing),

- medium flexible (agency contract, preliminary contract, staff leasing, job sharing, part-time working) (Eurofound 2015),

- partly flexible (contract for a probationary period, temporary contract, appointment, internship contract, seasonal work).

One of the most commonly used classifications of alternative forms of employment on the Polish labour market is as follows (Bąk 2009):

- labour employment - based on the labour law, such as: fixed-term contracts, part-time work, on-call work, telework;

- non-labour employment - based on the civil law, e.g. civil law contracts, self-employment;

- $\quad$ other - e.g. job sharing, staff leasing, outsourcing.

In conclusion, flexible forms of employment have many positive aspects. On the other hand, it should be emphasized that there are also reasons for criticism of the discussed forms of employment. According to the critical approach such models are unusual, uncertain, deviating from the prevailing rules and, therefore, bring anxiety and fear of the unknown (Krukowski and Oliński 2010). Flexible forms of employment can both increase or decrease innovativeness of companies and workers. The latter do not identify with the employer (Storey et al. 2002).

Labour employment includes those forms of contracts which are governed by the Labour Code. By operation of law, the employee is subordinated to his/her employer. He or she is protected by a wide range of employee rights. 
The main forms of labour employment include: temporary contract, probationary period contract, fixed-term contract, replacement employment contract, part-time work, on-call employment and teleworking.

The term "non-labour employment" is to be understood as such employment relationship which, in its form, is not subject to the Labour Code. This form of employment is used more and more often, due to the fact that it corresponds in a better way to the realities of the current labour market. The most common agreements of this type are: contract of mandate, contract for specific work, agency agreement, self-employment, job sharing, outsourcing (Dolgui and Proth 2013).

Flexible forms of employment are present in Poland and other European countries, such as France, Spain or Germany. In the last case, we can often come across the form of employment called "Geringfügige Beschäftigung" which is used for a fixed-term, part-time relationship (Eichhorst and Kendzia 2016; Buschoff and Protsch 2008). One can distinguish between two types of this form of employment, i.e. intended for businesses (the commercial sector), and for private households. The differences between them arise from different accounting methods and the amount of National Insurance contributions. In England, this atypical form of employment is called the "zero-hour contract". It includes a part-time job and on-call employment. According to this form, employees are entitled to annual leave and the minimum wage (Cheese 2015; Contract types and employer responsibilities). Summarising, Poland, Slovenia, Romania and Slovakia usually use the new employment forms identified mostly concern employees. At the same time, southern European countries, the Baltic States, Germany and Denmark usually generally involve the self-employed (Eurofound 2015).

\section{Data}

The research results presented are part of a broader study, which was based on the same research method and data. Thus, the description of the research method and data is applicable also to the results of research on other aspects of HRM and other papers by authors. The data from the survey, which was conducted from January 2016 to April 2016, were used to test the research thesis. The "snowball" technique was used in order to collect the data. The survey participants were invited by existing subjects. Personal contacts and individual visits to banks were used to collect the data. More than 20,000 queries were sent with a request to fill in the questionnaire via email, social networking websites (such as Facebook and GoldenLine) and thematic forums. Both an electronic version (Anonimowe Badanie Pracowników Banków 2016) and hard copy one of the questionnaire were used in the survey.

The main survey was preceded by a two-staged pilot survey. First, the survey was conducted on a small group of target participants (180 students). In the second stage, the target group consisted of 100 employees from the banking sector. The aim was to reveal any inconsistencies and to examine whether the questions were understandable. Thanks to the pilot study, the questionnaire was modified and improved.

The questionnaire consists of an introduction followed by 23 closed-ended questions and several demographic and work-related questions. The main part of the questionnaire contains questions which refer to seven important human resource management areas (recruitment, motivation, flexible forms of employment, organizational culture, mobbing, training and outplacement). Some of the questions were used to test the research thesis. Banking employees were asked about the form of current and the first form of employment. They could choose some of the forms listed or give own form of employment.

The questionnaires have been completed by 1,949 respondents. 29 questionnaires were rejected due to low credibility and reliability (for example, some respondents selected " 0 " in response to all of the closed-ended 
The International Journal

ENTREPRENEURSHIP AND SUSTAINABILITY ISSUES

ISSN 2345-0282 (online) http://jssidoi.org/jesi/

2018 Volume 6 Number 2 (December)

http://doi.org/10.9770/jesi.2018.6.2(21)

questions). As a result, the final research sample consists of 1,920 respondents (152 electronic version and 1,768 hard copy). Table 1 provides more details regarding the sample structure.

Table 1. Sample structure

\begin{tabular}{|c|c|c|c|}
\hline \multicolumn{2}{|r|}{ Criterion } & Number of individuals & Percentage \\
\hline \multirow{3}{*}{ Gender } & Female & 1,312 & $68.33 \%$ \\
\hline & Male & 473 & $24.64 \%$ \\
\hline & No answer & 135 & $7.03 \%$ \\
\hline \multirow{7}{*}{ Education } & University (major in economics) & 883 & $45.99 \%$ \\
\hline & University (other) & 515 & $26.82 \%$ \\
\hline & High school (major in economics) & 270 & $14.06 \%$ \\
\hline & High school (other) & 189 & $9.84 \%$ \\
\hline & Vocational & 2 & $0.1 \%$ \\
\hline & Elementary & 2 & $0.1 \%$ \\
\hline & No answer & 59 & $3.1 \%$ \\
\hline \multirow{5}{*}{ Occupied position } & Senior managerial position & 43 & $2.24 \%$ \\
\hline & Middle-level managerial position & 129 & $6.72 \%$ \\
\hline & Lower-level managerial position & 153 & $7.97 \%$ \\
\hline & Non-managerial position & 1,485 & $77.34 \%$ \\
\hline & No answer & 110 & $5.73 \%$ \\
\hline \multirow{4}{*}{ Organizational unit } & Headquarters & 409 & $21.3 \%$ \\
\hline & Regional branch & 416 & $21.66 \%$ \\
\hline & Operational branch & 1,020 & $53.13 \%$ \\
\hline & No answer & 75 & $3.91 \%$ \\
\hline \multirow{3}{*}{ Type of bank } & Commercial bank & 1,342 & $69.90 \%$ \\
\hline & Cooperative bank & 481 & $25.05 \%$ \\
\hline & No answer & 97 & $5.05 \%$ \\
\hline \multirow{3}{*}{ The equity } & National & 919 & $47.86 \%$ \\
\hline & Foreign & 863 & $44.95 \%$ \\
\hline & No answer & 138 & $7.19 \%$ \\
\hline \multirow{3}{*}{ Workplace } & Front office & 1,118 & $58.23 \%$ \\
\hline & Back office & 460 & $23.96 \%$ \\
\hline & No answer & 342 & $17.81 \%$ \\
\hline \multirow{5}{*}{ Disability } & Lack & 1,820 & $94.79 \%$ \\
\hline & Slight level & 12 & $0.63 \%$ \\
\hline & Moderate level & 8 & $0.42 \%$ \\
\hline & Significant level & 2 & $0.1 \%$ \\
\hline & No answer & 78 & $4.06 \%$ \\
\hline
\end{tabular}

Source: own computations based on the survey data.

The composition of the research sample according to gender, type of education and type of bank corresponds to the structure of employment in the banking sector in Poland (2011). The mean age of respondents was 36,6 years. The mean work experience in banking was 12,1 years, ranging from 1 to 43 years. The mean total work experience of respondents was 15,0 years (Table 2).

Table 2. Summary statistics on age and work experience

\begin{tabular}{|c|c|c|c|c|c|}
\hline Criterion & Minimum & Maximum & Mean & Median & Standard deviation \\
\hline Age & 19 & 64 & 36.612 & 35 & 9.7496 \\
\hline Work experience in banking & 1 & 43 & 12.065 & 10 & 9.5799 \\
\hline Work experience with current employer & 1 & 43 & 9.835 & 7 & 9.3882 \\
\hline Total work experience & 1 & 45 & 14.976 & 12 & 10.2416 \\
\hline
\end{tabular}

Source: own computations based on the survey data. 
The International Journal

ENTREPRENEURSHIP AND SUSTAINABILITY ISSUES

ISSN 2345-0282 (online) http://jssidoi.org/jesi/

2018 Volume 6 Number 2 (December)

http://doi.org/10.9770/jesi.2018.6.2(21)

The locality size criterion demonstrates that the largest group of respondents came from the localities inhabited by 50 thousand people, the fewest surveyed people coming from localities with 200-500 thousand inhabitants (Table $3)$.

Table 3. Summary statistics on place of residence

\begin{tabular}{|c|c|c|c|}
\hline \multirow{4}{*}{ Size of locality } & Up to 50 thous people & 658 & $34.27 \%$ \\
\cline { 2 - 4 } & $50-100$ thous people & 251 & $13.07 \%$ \\
\cline { 2 - 4 } & $100-200$ thous people & 245 & $12.76 \%$ \\
\cline { 2 - 4 } & 200-500 thous people & 124 & $6.46 \%$ \\
\cline { 2 - 4 } & More than 500 thous people & 541 & $28.18 \%$ \\
\cline { 2 - 4 } & No answer & 101 & $5.26 \%$ \\
\hline
\end{tabular}

Source: own computations based on the survey data.

\section{Empirical analysis}

A majority $(74.1 \%)$ of bank employees are employed at the beginning of their professional career by means of different types of flexible contracts different time span, defined by employer (60.5\% on a fixed-term contract). Only $18.8 \%$ could eventually count on an indefinite employment contract, which gives them the most employment privileges and the highest social security. Nearly $8 \%$ of the bankers at early stages of their careers are employed under contracts of mandate or contracts for specific work, and $9.5 \%$ work on temporary contracts (probationary period contracts or replacement employment contracts).

Table 4. First and current forms of employment - basic statistics

\begin{tabular}{|c|c|c|}
\hline & First form of employment & Current form of employment \\
\cline { 2 - 3 } & $\% ;$ number of answers & $\% ;$ number of answers \\
\hline Indefinite employment contract & $18.8 \% ; 361$ & $66.1 \% ; 1,270$ \\
\hline Fixed term contract & $60.5 \% ; 1,162$ & $21.0 \% ; 404$ \\
\hline Agency agreement & $7.9 \% ; 152$ & $2.0 \% ; 39$ \\
\hline Work contracting & $1.3 \% ; 24$ & $0.8 \% ; 16$ \\
\hline Self-employment & $0.5 \% ; 9$ & $0.6 \% ; 11$ \\
\hline Teleworking & $0.7 \% ; 13$ & $0.6 \% ; 12$ \\
\hline Job sharing & $0.4 \% ; 8$ & $8.5 \% ; 163$ \\
\hline Probationary period contract, replacement employment contract & $0.3 \% ; 6$ & $0.4 \% ; 8$ \\
\hline On-call employment & $9.5 \% ; 183$ & $1.8 \% ; 35$ \\
\hline Others & $0.1 \% ; 2$ & $0.1 \% ; 2$ \\
\hline All flexible forms of employment together & - & $0.1 \% ; 2$ \\
\hline No answer & $74.1 \%, 1,423$ & $25.5 \% ; 489$ \\
\hline
\end{tabular}

Source: own computations based on the survey data.

The structure of the forms of employment in the case of further employment (current form of employment) looks completely different (Table 4). Most of the employees work under an indefinite employment contract (66.1\%). Various flexible forms of employment apply to $25.5 \%$ of the employees. The most common form is the fixedterm contract and teleworking (8.5\%).

The main thesis argued: flexible forms of employment are more common among young people starting their professional activity than senior workers. The thesis was confirmed both in reference to the first, and current forms of employment. Application of flexible forms of employment is facilitated by: the employee's young age (up to 35 years), short experience with the current employer (up to 7 years), short work experience in banking (up to 10 years), and short total work experience (up to 12 years). All of these factors interacted equally with the use 
The International Journal

ENTREPRENEURSHIP AND SUSTAINABILITY ISSUES

ISSN 2345-0282 (online) http://jssidoi.org/jesi/ 2018 Volume 6 Number 2 (December)

http://doi.org/10.9770/jesi.2018.6.2(21)

of flexible forms of employment. It means that both in the case of the first and the next jobs, more seniority and more experience foster employment on the basis of an employment contract for an indefinite period. The proportion of young employees working under flexible forms of employment was several times higher than of employees with longer experience. For example, up to $41.7 \%$ of employees up to 35 years of age were employed (currently) within the framework of flexible forms of employment. At the same time, the proportion of older employees (over 35 years) being employed on the basis of these forms of employment was only 13.7\%. In accordance with the assumptions as adopted earlier, the increase in the use of flexible forms of employment, promotes the decrease of employment based on the traditional employment contract for an indefinite period (Table 5 and 6).

Green Line research shows that flexible forms of employment can be particularly beneficial for learners (73\%), as well as for people taking up a job for the first time (25\%) and they allow to combine work with study and personal life (25\%) (Zielona Linia 2011). Moreover, according to R. Muster's research, young people indicate that flexible forms of employment allow them to combine work and education. At the same time, they reduce their creditworthiness (2012). Often, atypical employment is forced on their part by an employer who does not want to increase labor costs and employ them on the basis of an employment contract for an unspecified period of time. The young declared that they would willingly change the form of employment if they only could.

Table 5. First form of employment in different groups - population and seniority

\begin{tabular}{|c|c|c|c|c|c|c|}
\hline \multirow[b]{2}{*}{ Group } & \multicolumn{2}{|c|}{$\begin{array}{c}\text { Indefinite employment contract; \%; } \\
\text { number of answers }\end{array}$} & \multicolumn{2}{|c|}{$\begin{array}{l}\text { All flexible forms of employment } \\
\text { together; \%; number of answers }\end{array}$} & \multicolumn{2}{|c|}{$\begin{array}{l}\text { Fixed term contract; \%; number } \\
\text { of answers }\end{array}$} \\
\hline & $\begin{array}{l}\text { Chi-squared; df; } \\
\text { significance; Phi } \\
\text { Yula/ V Cramera }\end{array}$ & answers & $\begin{array}{l}\text { Chi-squared; df; } \\
\text { significance; Phi } \\
\text { Yula/ V Cramera }\end{array}$ & answers & $\begin{array}{l}\text { Chi-squared; df; } \\
\text { significance; Phi } \\
\text { Yula/ V Cramera }\end{array}$ & answers \\
\hline Female & \multirow{2}{*}{$\begin{array}{c}4.832 ; 1 ; 0.028 ; \\
0.054\end{array}$} & $21.8 \% ; 265$ & \multirow{2}{*}{$\begin{array}{c}4.800 ; 1 ; \mathbf{0 . 0 2 8} \\
0.054\end{array}$} & $78.2 \% ; 950$ & \multirow{2}{*}{$\begin{array}{c}0.061 ; 1 ; 0.805 \\
0.006\end{array}$} & $64.8 \% ; 787$ \\
\hline Male & & $16.9 \% ; 76$ & & $83.1 \% ; 373$ & & $65.5 \% ; 294$ \\
\hline Up to 50 thous people & \multirow{5}{*}{$\begin{array}{c}18.529 ; 4 ; 0.001 \\
0.105\end{array}$} & $21.3 \% ; 130$ & \multirow{5}{*}{$\begin{array}{c}18.503 ; 4 ; 0.001 \\
0.104\end{array}$} & $78.8 \% ; 482$ & \multirow{5}{*}{$\begin{array}{c}8.509 ; 4 ; 0.075 \\
0.071\end{array}$} & $65.0 \% ; 397$ \\
\hline 50-100 thous people & & $27.7 \% ; 64$ & & $72.3 \% ; 167$ & & $61.0 \% ; 141$ \\
\hline $100-200$ thous peole & & $13.4 \% ; 31$ & & $86.6 \% ; 200$ & & $71.9 \% ; 166$ \\
\hline $200-500$ thous people & & $22.6 \% ; 26$ & & $77.4 \% ; 89$ & & $59.1 \% ; 68$ \\
\hline $\begin{array}{c}\text { Above } 500 \text { thous } \\
\text { people }\end{array}$ & & $17.2 \% ; 87$ & & $82.8 \% ; 420$ & & $66.5 \% ; 337$ \\
\hline $\begin{array}{l}\text { Senior managerial } \\
\text { position }\end{array}$ & \multirow{4}{*}{$\begin{array}{c}5.647 ; 3 ; 0.130 \\
0.058\end{array}$} & $33.3 \% ; 14$ & \multirow{4}{*}{$\begin{array}{c}5.664 ; 3 ; 0.129 \\
0.058\end{array}$} & $66.7 \% ; 28$ & \multirow{4}{*}{$\begin{array}{c}1.561 ; 3 ; 0.668 \\
0.030\end{array}$} & $59.5 \% ; 25$ \\
\hline $\begin{array}{c}\text { Middle-level } \\
\text { managerial position }\end{array}$ & & $23.3 \% ; 27$ & & $76.7 \% ; 89$ & & $69.0 \% ; 80$ \\
\hline $\begin{array}{c}\text { Lower-level } \\
\text { managerial position }\end{array}$ & & $19.6 \% ; 29$ & & $80.4 \% ; 119$ & & $66.2 \% ; 98$ \\
\hline $\begin{array}{l}\text { Non-managerial } \\
\text { position }\end{array}$ & & $19.5 \% ; 270$ & & $\begin{array}{c}80.5 \% \\
1,116\end{array}$ & & $64.5 \% ; 894$ \\
\hline
\end{tabular}

Source: own computations based on the survey data. 
The International Journal

ENTREPRENEURSHIP AND SUSTAINABILITY ISSUES

ISSN 2345-0282 (online) http://jssidoi.org/jesi/

2018 Volume 6 Number 2 (December)

http://doi.org/10.9770/jesi.2018.6.2(21)

Table 6. First form of employment in different groups - education, type of bank, age

\begin{tabular}{|c|c|c|c|c|c|c|}
\hline \multirow[b]{2}{*}{ Group } & \multicolumn{2}{|c|}{$\begin{array}{l}\text { Indefinite employment contract; } \\
\% \text {; number of answers }\end{array}$} & \multicolumn{2}{|c|}{$\begin{array}{l}\text { All flexible forms of employment } \\
\text { together; } \% \text {; number of answers }\end{array}$} & \multicolumn{2}{|c|}{$\begin{array}{l}\text { Fixed term contract; \%; number of } \\
\text { answers }\end{array}$} \\
\hline & $\begin{array}{l}\text { Chi-squared; df; } \\
\text { significance; Phi } \\
\text { Yula/ V Cramera }\end{array}$ & answers & $\begin{array}{l}\text { Chi-squared; df; } \\
\text { significance; Phi } \\
\text { Yula/ V Cramera }\end{array}$ & answers & $\begin{array}{l}\text { Chi-squared; df; } \\
\text { significance; Phi } \\
\text { Yula/ V Cramera }\end{array}$ & answers \\
\hline $\begin{array}{l}\text { University (major in } \\
\text { economics) }\end{array}$ & \multirow{6}{*}{$\begin{array}{c}36.657 ; 5 ; 0.000 \\
0.145\end{array}$} & $\underline{18.8 \% ; 156}$ & \multirow{6}{*}{$\begin{array}{c}4.800 ; 1 ; 0.028 \\
0.054\end{array}$} & $81.3 \% ; 676$ & \multirow{6}{*}{$\begin{array}{c}26.195 ; 5 ; \mathbf{0 . 0 0 0} ; \\
0.123\end{array}$} & $67.5 \% ; 561$ \\
\hline University (other) & & $15.0 \% ; 71$ & & $85.0 \% ; 401$ & & $69.1 \% ; 326$ \\
\hline $\begin{array}{l}\text { High school (major in } \\
\text { economics) }\end{array}$ & & $\underline{30.8 \% ; 78}$ & & $\underline{69.2 \% ; 175}$ & & 53.4\%; 135 \\
\hline High school (other) & & $24.0 \% ; 42$ & & $76.0 \% ; 133$ & & $62.3 \% ; 109$ \\
\hline Vocational education & & $100.0 \% ; 2$ & & $0.0 \%$ & & $0.0 \%$ \\
\hline Elementary education & & $0.0 \%$ & & $100.0 \% ; 2$ & & $100.0 \% ; 2$ \\
\hline Commercial bank & \multirow{2}{*}{$\begin{array}{c}1.509 ; 1 ; 0.219 \\
0.030\end{array}$} & $19.4 \% ; 242$ & \multirow{2}{*}{$\begin{array}{c}1.458 ; 1 ; 0.227 \\
0.029\end{array}$} & $\begin{array}{c}80.6 \% \\
1007\end{array}$ & \multirow{2}{*}{$\begin{array}{c}4.699 ; 1 ; \mathbf{0 . 0 3 0} \\
0.053\end{array}$} & $63.7 \% ; 795$ \\
\hline Cooperative bank & & $22.1 \% ; 100$ & & $78.0 \% ; 354$ & & $69.3 \% ; 314$ \\
\hline $\begin{array}{c}\text { Banks with majority of } \\
\text { national capital }\end{array}$ & \multirow{2}{*}{$\begin{array}{c}\text { 7.943; } 1 ; 0.005 \\
0.069\end{array}$} & $\underline{23.2 \% ; 198}$ & \multirow{2}{*}{$\begin{array}{c}7.873 ; 1 ; 0.005 \\
0.069\end{array}$} & 76.8\%; 655 & \multirow{2}{*}{$\begin{array}{c}1.065 ; 1 ; 0.302 \\
0.025\end{array}$} & $63.4 \% ; 540$ \\
\hline $\begin{array}{l}\text { Banks with majority of } \\
\text { foreign capital }\end{array}$ & & $\underline{17.7 \% ; 143}$ & & $\underline{82.3 \% ; 667}$ & & $65.8 \% ; 533$ \\
\hline 35 years and under & \multirow{2}{*}{$\begin{array}{c}36.705 ; 5 ; 0.000 \\
0.145\end{array}$} & $9.4 \% ; 85$ & \multirow{2}{*}{$\begin{array}{l}132.135 ; 1 ; \\
0.000 ; 0.272\end{array}$} & $90.6 \% ; 817$ & \multirow{2}{*}{$\begin{array}{c}11.533 ; 1 ; 0.001 \\
0.080\end{array}$} & $69.0 \% ; 622$ \\
\hline Above 35 years old & & $31.3 \% ; 276$ & & $68.7 \% ; 606$ & & $61.3 \% ; 540$ \\
\hline
\end{tabular}

Source: own computations based on the survey data.

Table 7. First form of employment in different groups - work experience

\begin{tabular}{|c|c|c|c|c|c|c|}
\hline \multirow[b]{2}{*}{ Group } & \multicolumn{2}{|c|}{$\begin{array}{l}\text { Indefinite employment contract; \%; } \\
\text { number of answers }\end{array}$} & \multicolumn{2}{|c|}{$\begin{array}{l}\text { All flexible forms of employment } \\
\text { together; \%; number of answers }\end{array}$} & \multicolumn{2}{|c|}{$\begin{array}{l}\text { Fixed term contract; } \% \text {; number of } \\
\text { answers }\end{array}$} \\
\hline & $\begin{array}{l}\text { Chi-squared; df; } \\
\text { significance; Phi } \\
\text { Yula/ V Cramera }\end{array}$ & answers & $\begin{array}{l}\text { Chi-squared; df; } \\
\text { significance; Phi } \\
\text { Yula/ V Cramera }\end{array}$ & answers & $\begin{array}{l}\text { Chi-squared; df; } \\
\text { significance; Phi } \\
\text { Yula/ V Cramera }\end{array}$ & answers \\
\hline $\begin{array}{c}7 \text { years work } \\
\text { experience with } \\
\text { current employer and } \\
\text { under (median) }\end{array}$ & \multirow{2}{*}{$\begin{array}{c}108.567 ; 1 ; 0.000 \\
0.247\end{array}$} & $\underline{10.3 \% ; 92}$ & \multirow{2}{*}{$\begin{array}{l}108.303 ; 1 ; \\
0.000 ; 0.246\end{array}$} & $\underline{89.7 \% ; 799}$ & \multirow{2}{*}{$\begin{array}{c}6.850 ; 1 ; 0.009 \\
0.062\end{array}$} & $68.1 \% ; 607$ \\
\hline $\begin{array}{l}\text { Above } 7 \text { years work } \\
\text { experience with } \\
\text { current employer } \\
\text { (median) }\end{array}$ & & $\underline{30.2 \% ; 269}$ & & $\underline{69.9 \% ; 624}$ & & $62.2 \% ; 555$ \\
\hline $\begin{array}{l}10 \text { years and under } \\
\text { work experience in } \\
\text { banking (median) }\end{array}$ & \multirow{2}{*}{$\begin{array}{c}117.813 ; 1 ; 0.000 ; \\
0.257\end{array}$} & $10.9 \% ; 107$ & \multirow{2}{*}{$\begin{array}{l}117.495 ; 1 ; \\
0.000 ; 0.257\end{array}$} & $\underline{89.1 \% ; 874}$ & \multirow{2}{*}{$\begin{array}{c}16.516 ; 1 ; 0.000 \\
0.096\end{array}$} & $\underline{69.3 \% ; 680}$ \\
\hline $\begin{array}{l}\text { Above } 10 \text { years work } \\
\text { experience in banking } \\
\text { (median) }\end{array}$ & & $\underline{31.7 \% ; 254}$ & & $\underline{68.4 \% ; 549}$ & & $\underline{60.1 \% ; 482}$ \\
\hline $\begin{array}{c}12 \text { years and under } \\
\text { total work experiance } \\
\text { (median) }\end{array}$ & \multirow{2}{*}{$\begin{array}{c}125.861 ; 1 ; 0.000 ; \\
0.266\end{array}$} & $9.4 \% ; 83$ & \multirow{2}{*}{$\begin{array}{l}125.581 ; 1 ; \\
0.000 ; 0.265\end{array}$} & $\underline{90.6 \% ; 797}$ & \multirow{2}{*}{$\begin{array}{c}9.193 ; 1 ; 0.002 \\
0.072\end{array}$} & $\underline{68.6 \% ; 604}$ \\
\hline $\begin{array}{c}\text { Above } 12 \text { years total } \\
\text { work experience } \\
\text { (median) }\end{array}$ & & $\underline{30.8 \% ; 278}$ & & $\underline{69.2 \% ; 626}$ & & $\underline{61.8 \% ; 558}$ \\
\hline
\end{tabular}

Source: own computations based on the survey data. 
The International Journal

ENTREPRENEURSHIP AND SUSTAINABILITY ISSUES

ISSN 2345-0282 (online) http://jssidoi.org/jesi/

2018 Volume 6 Number 2 (December)

http://doi.org/10.9770/jesi.2018.6.2(21)

The thesis also corroborated that (in the case of current form of employment): flexible forms of employment occur less often in managerial positions than in non-managerial ones. Managers were more often than nonexecutives employed under indefinite employment contracts. For example, up to $92.5 \%$ of senior managers and only $69.1 \%$ of non-managerial employees were employed on the basis of indefinite employment contracts. Employment under the indefinite employment contract is the prevailing form of employment for managers. The analysis clearly separates senior managers from non-managerial employees, the two being at opposite poles with reference to the method of employment. The Green Line report also indicates that flexible forms of employment are relatively rarely used in managerial positions (Zielona Linia 2011). Other results were obtained by BąkGrabowska and Jagoda. Empirical studies conducted among 397 empoployees at 49 enterprises in Poland confirmed that management staff is less than other workers employed on the basis of contract of employment and more often on the basis of self-employment. At the same time they are almost never employed on the basis of civil-law contract (2016). One can suspect that bank managers are employed on more stable terms than employees in other sectors. In addition, the specificity of the bank as a public trust institution forces (at least in theory) a greater bond between the employee and the bank. With respect to education, it has been noted that there are differences between people with economic education and non-economic one (regarding both the first and the current forms of employment). Employees with economic education were employed under flexible forms of employment less often than their non-economic counterparts. Simultaneously, they were hired more often on the basis of indefinite employment contracts. Whereas in the case of the first contract of employment, the differences in the responses did not exceed 10 percentage points, this usually slightly increased in time with respect to the current employment contract. The conclusion is that it pays off to have economic education working at bank, which is conducive for employment stability. The type of education (economic vs. non-economic) has become increasingly important for forms of employment. Economic education gave employees greater stability. One may suspect that employees with economic education are the core of employees, and those who do not have economic education can assume supporting roles (and undertake auxiliary activities). This would be consistent with the concept of shamrock organization by Ch. Handy (2014). The shamrock organization model is a leaf shape symbolic representation with three types of workforce (core staff, contractual fringe, consultancy). Probably workers with different education level represent different "leafs". Its relation however require confirmation by additional studies.

\begin{tabular}{|c|c|c|c|c|c|c|}
\hline \multirow[b]{2}{*}{ Group } & \multicolumn{2}{|c|}{$\begin{array}{l}\text { Indefinite employment contract; \%; } \\
\text { number of answers }\end{array}$} & \multicolumn{2}{|c|}{$\begin{array}{l}\text { All flexible forms of employment } \\
\text { together; \%; number of answers }\end{array}$} & \multicolumn{2}{|c|}{$\begin{array}{l}\text { Fixed term contract; \%; number of } \\
\text { answers }\end{array}$} \\
\hline & $\begin{array}{l}\text { Chi-squared; df; } \\
\text { significance; Phi } \\
\text { Yula/ V Cramera }\end{array}$ & answers & $\begin{array}{l}\text { Chi-squared; df; } \\
\text { significance; Phi } \\
\text { Yula/ V Cramera }\end{array}$ & answers & $\begin{array}{l}\text { Chi-squared; df; } \\
\text { significance; Phi } \\
\text { Yula/ V Cramera }\end{array}$ & answers \\
\hline Female & \multirow{2}{*}{$\begin{array}{c}1.761 ; 1 ; 0.185 \\
0.033\end{array}$} & $72,9 \% ; 874$ & \multirow{2}{*}{$\begin{array}{c}1.696 ; 1 ; 0.193 \\
0.032\end{array}$} & $27.2 \% ; 326$ & \multirow{2}{*}{$\begin{array}{c}3.159 ; 1 ; 0.075 \\
0.044\end{array}$} & $22.1 \% ; 265$ \\
\hline Male & & $69.6 \% ; 304$ & & $30.4 \% ; 133$ & & $26.3 \% ; 115$ \\
\hline Up to 50 thous people & \multirow{5}{*}{$\begin{array}{c}50.419 ; 4 ; 0.000 \\
0.173\end{array}$} & $80.5 \% ; 491$ & \multirow{5}{*}{$\begin{array}{c}49.948 ; 4 ; 0.000 \\
0.173\end{array}$} & $19.5 \% ; 119$ & \multirow{5}{*}{$\begin{array}{c}27.491 ; 1 ; 0.000 \\
0.128\end{array}$} & $17.5 \% ; 107$ \\
\hline 50-100 thous people & & $78.0 \% ; 184$ & & $22.4 \% ; 53$ & & $19.1 \% ; 45$ \\
\hline $100-200$ thous peole & & $65.0 \% ; 147$ & & $35.0 \% ; 79$ & & $29.6 \% ; 67$ \\
\hline 200-500 thous people & & $63.2 \% ; 67$ & & $36.8 \% ; 39$ & & $32.1 \% ; 34$ \\
\hline $\begin{array}{l}\text { Above } 500 \text { thous } \\
\text { people }\end{array}$ & & $\underline{64.3 \% ; 320}$ & & $\underline{35.7 \% ; 178}$ & & $\underline{27.1 \% ; 135}$ \\
\hline $\begin{array}{c}\text { Senior managerial } \\
\text { position }\end{array}$ & \multirow{4}{*}{$\begin{array}{c}26.427 ; 3 ; 0.000 ; \\
0.126\end{array}$} & $92.5 \% ; 37$ & \multirow{4}{*}{$\begin{array}{c}26.583 ; 3 ; 0.000 \\
0.126\end{array}$} & $7.5 \% ; 3$ & \multirow{4}{*}{$\begin{array}{c}21.722 ; 3 ; 0.000 \\
0.114\end{array}$} & $2.5 \% ; 1$ \\
\hline $\begin{array}{c}\text { Middle-level } \\
\text { managerial position }\end{array}$ & & $81.3 \% ; 100$ & & $18.7 \% ; 23$ & & $13.8 \% ; 17$ \\
\hline $\begin{array}{c}\text { Lower-level } \\
\text { managerial position }\end{array}$ & & $82.2 \% ; 120$ & & $17.8 \% ; 26$ & & $17.8 \% ; 26$ \\
\hline $\begin{array}{l}\text { Non-managerial } \\
\text { position }\end{array}$ & & $69.1 \% ; 939$ & & $30.9 \% ; 420$ & & $25.4 \% ; 345$ \\
\hline
\end{tabular}

Source: own computations based on the survey data 
The International Journal

ENTREPRENEURSHIP AND SUSTAINABILITY ISSUES

ISSN 2345-0282 (online) http://jssidoi.org/jesi/

2018 Volume 6 Number 2 (December)

http://doi.org/10.9770/jesi.2018.6.2(21)

Table 9. Current form of employment in different groups - education, type of bank, age

\begin{tabular}{|c|c|c|c|c|c|c|}
\hline \multirow[b]{2}{*}{ Group } & \multicolumn{2}{|c|}{$\begin{array}{l}\text { Indefinite employment contract; \%; } \\
\text { number of answers }\end{array}$} & \multicolumn{2}{|c|}{$\begin{array}{l}\text { All flexible forms of employment } \\
\text { together; \%; number of answers }\end{array}$} & \multicolumn{2}{|c|}{$\begin{array}{l}\text { Fixed term contract; } \% ; \text { number } \\
\text { of answers }\end{array}$} \\
\hline & $\begin{array}{l}\text { Chi-squared; df; } \\
\text { significance; Phi } \\
\text { Yula/ V Cramera }\end{array}$ & answers & $\begin{array}{l}\text { Chi-squared; df; } \\
\text { significance; Phi } \\
\text { Yula/ V Cramera }\end{array}$ & answers & $\begin{array}{l}\text { Chi-squared; df; } \\
\text { significance; Phi } \\
\text { Yula/ V Cramera }\end{array}$ & answers \\
\hline $\begin{array}{c}\text { University (major in } \\
\text { economics) }\end{array}$ & \multirow{6}{*}{$\begin{array}{c}29.719 ; 5 ; 0.000 ; \\
0.132\end{array}$} & $\underline{76.2 \% ; 634}$ & \multirow{6}{*}{$\begin{array}{c}29.975 ; 5 ; 0.000 \\
0.133\end{array}$} & $\underline{23.9 \% ; 199}$ & \multirow{6}{*}{$\begin{array}{c}16.871 ; 5 ; 0.005 \\
0.099\end{array}$} & $\underline{20.9 \% ; 174}$ \\
\hline University (other) & & $65.2 \% ; 304$ & & $\underline{34.8 \% ; 162}$ & & $\underline{29.0 \% ; 135}$ \\
\hline $\begin{array}{l}\text { High school (major in } \\
\text { economics) }\end{array}$ & & 78.0\%; 184 & & $\underline{22.0 \% ; 52}$ & & $\underline{17.8 \% ; 42}$ \\
\hline High school (other) & & $\underline{63.5 \% ; 106}$ & & $\underline{36.9 \% ; 62}$ & & $25.7 \% ; 43$ \\
\hline Vocational education & & $100.0 \% ; 2$ & & $\underline{0.0 \%}$ & & $\underline{0.0 \%}$ \\
\hline Elementary education & & $100.0 \% ; 2$ & & $\underline{0.0 \%}$ & & $\underline{0.0 \%}$ \\
\hline Commercial bank & \multirow{2}{*}{$\begin{array}{c}19.259 ; 1 ; 0.000 \\
0.107\end{array}$} & $69.0 \% ; 847$ & \multirow{2}{*}{$\begin{array}{c}19.443 ; 1 ; 0.000 \\
0.108 \\
\end{array}$} & $31.1 \% ; 382$ & \multirow{2}{*}{$\begin{array}{c}9.791 ; 1 ; \mathbf{0 . 0 0 2} \\
0.077 \\
\end{array}$} & $25.4 \% ; 312$ \\
\hline Cooperative bank & & $79.9 \% ; 354$ & & $20.1 \% ; 89$ & & $18.1 \% ; 80$ \\
\hline $\begin{array}{c}\text { Banks with majority } \\
\text { of national capital }\end{array}$ & \multirow{2}{*}{$\begin{array}{c}16.582 ; 1 ; 0.000 \\
0.101\end{array}$} & $76.5 \% ; 641$ & \multirow{2}{*}{$\begin{array}{c}16.545 ; 1 ; 0.000 \\
0.100\end{array}$} & $\underline{23.6 \% ; 198}$ & \multirow{2}{*}{$\begin{array}{c}7.605 ; 1 ; 0.006 \\
0.068\end{array}$} & $\underline{20.3 \% ; 170}$ \\
\hline $\begin{array}{l}\text { Banks with majority } \\
\text { of foreign capital }\end{array}$ & & $\underline{67.5 \% ; 539}$ & & $\underline{32.6 \% ; 261}$ & & $\underline{26.0 \% ; 208}$ \\
\hline 35 years and under & \multirow{2}{*}{$\begin{array}{c}169.835 ; 1 ; 0.000 ; \\
0.311\end{array}$} & $\underline{58.4 \% ; 516}$ & \multirow{2}{*}{$\begin{array}{l}171.331 ; 1 ; \\
0.000 ; 0.312\end{array}$} & $41.7 \% ; 369$ & \multirow{2}{*}{$\begin{array}{l}123.129 ; 1 ; \\
0.000 ; 0.265\end{array}$} & $\underline{34.1 \% ; 301}$ \\
\hline Above 35 years old & & $\underline{86.3 \% ; 754}$ & & $13.7 \% ; 120$ & & $11.8 \% ; 103$ \\
\hline
\end{tabular}

Source: own computations based on the survey data.

Table 10. Current form of employment in different groups - experience

\begin{tabular}{|c|c|c|c|c|c|c|}
\hline \multirow[b]{2}{*}{ Group } & \multicolumn{2}{|c|}{$\begin{array}{l}\text { Indefinite employment contract; \%; } \\
\text { number of answers }\end{array}$} & \multicolumn{2}{|c|}{$\begin{array}{l}\text { All flexible forms of employment } \\
\text { together; \%; number of answers }\end{array}$} & \multicolumn{2}{|c|}{$\begin{array}{l}\text { Fixed term contract; \%; number } \\
\text { of answers }\end{array}$} \\
\hline & $\begin{array}{l}\text { Chi-squared; df; } \\
\text { significance; Phi } \\
\text { Yula/ V Cramera } \\
\end{array}$ & answers & $\begin{array}{l}\text { Chi-squared; df; } \\
\text { significance; Phi } \\
\text { Yula/ V Cramera }\end{array}$ & answers & $\begin{array}{l}\text { Chi-squared; df; } \\
\text { significance; Phi } \\
\text { Yula/ V Cramera }\end{array}$ & answers \\
\hline $\begin{array}{c}7 \text { years work } \\
\text { experience with } \\
\text { current employer and } \\
\text { under (median) }\end{array}$ & \multirow{2}{*}{$\begin{array}{c}222.651 ; 1 ; 0.000 \\
0.356\end{array}$} & $\underline{56.1 \% ; 486}$ & \multirow{2}{*}{$\begin{array}{l}222.025 ; 1 ; \\
0.000 ; 0.355\end{array}$} & $43.9 \% ; 381$ & \multirow{2}{*}{$\begin{array}{l}158.451 ; 1 ; \\
0.000 ; 0.300\end{array}$} & $\underline{35.8 \% ; 310}$ \\
\hline $\begin{array}{l}\text { Above } 7 \text { years work } \\
\text { experience with } \\
\text { current employer } \\
\text { (median) }\end{array}$ & & $\underline{88.0 \% ; 784}$ & & $\underline{12.1 \% ; 108}$ & & $10.5 \% ; 94$ \\
\hline $\begin{array}{l}10 \text { years and under } \\
\text { work experience in } \\
\text { banking (median) }\end{array}$ & \multirow{2}{*}{$\begin{array}{c}168.296 ; 1 ; 0.000 \\
0.309\end{array}$} & $\underline{59.6 \% ; 572}$ & \multirow{2}{*}{$\begin{array}{l}\text { 167.613; } ; \\
0.000 ; 0.309\end{array}$} & $\underline{40.4 \% ; 388}$ & \multirow{2}{*}{$\begin{array}{l}125.492 ; 1 ; \\
0.000 ; 0.267\end{array}$} & $\underline{33.3 \% ; 319}$ \\
\hline $\begin{array}{l}\text { Above } 10 \text { years work } \\
\text { experience in banking } \\
\text { (median) }\end{array}$ & & $\underline{87.5 \% ; 698}$ & & $12.6 \% ; 101$ & & $\underline{10.7 \% ; 85}$ \\
\hline $\begin{array}{c}12 \text { years and under } \\
\text { total work experiance } \\
\text { (median) }\end{array}$ & \multirow{2}{*}{$\begin{array}{c}170.950 ; 1 ; 0.000 \\
0.312\end{array}$} & $\underline{58.0 \% ; 499}$ & \multirow{2}{*}{$\begin{array}{l}170.487 ; 1 ; \\
0.000 ; 0.311\end{array}$} & $\underline{42.0 \% ; 362}$ & \multirow{2}{*}{$\begin{array}{l}131.603 ; 1 ; \\
0.000 ; 0.274\end{array}$} & $34.8 \% ; 299$ \\
\hline $\begin{array}{c}\text { Above } 12 \text { years total } \\
\text { work experience } \\
\text { (median) }\end{array}$ & & $\underline{86.0 \% ; 771}$ & & $14.1 \% ; 127$ & & $11.7 \% ; 105$ \\
\hline
\end{tabular}

Source: own computations based on the survey data. 


\section{The International Journal}

ENTREPRENEURSHIP AND SUSTAINABILITY ISSUES

ISSN 2345-0282 (online) http://jssidoi.org/jesi/

2018 Volume 6 Number 2 (December)

http://doi.org/10.9770/jesi.2018.6.2(21)

In case of the current form of employment, it turned out that commercial banks more often than cooperative ones tap flexible forms of employment and concurrently less often use indefinite employment contract. This can be explained by the more corporate nature of commercial banks, another way of managing them and a different organizational culture of these two types of banks (2008). The staff at commercial banks are younger, they have less seniority (shorter length of service with the current employer) in banking and shorter total work experience (The average age of an employee at commercial banks was 35.03 and at cooperative banks $41.16(\mathrm{~F}=34.218$, $\mathrm{p}=0.000, \mathrm{t}=-10.811, \mathrm{df}=647.934, \mathrm{p}=0.000)$. The average length of work experience with current employer at commercial banks was 8.32 and at cooperative banks $13.96(\mathrm{~F}=87.746, \mathrm{p}=0.000, \mathrm{t}=-9.583, \mathrm{df}=590.630, \mathrm{p}=0.000)$. The average length of work experience in banking at commercial banks was 10.58 and at cooperative banks 15.99 $(\mathrm{F}=105.328, \mathrm{p}=0.000, \mathrm{t}=-9.127, \mathrm{df}=611.426, \mathrm{p}=0.000)$. The average length of total work experience at commercial banks was 13.37 and at cooperative banks $19.28(\mathrm{~F}=75.984, \mathrm{p}=0.000, \mathrm{t}=-9.748, \mathrm{df}=648.432$, $\mathrm{p}=0.000)$ ). In addition, they are rarely absent from work, which reflects a higher level of employee discipline than of those who work in cooperative banks (The average number of days absent from work in the last year (not including annual leave) at commercial banks was 9.5 and at cooperative banks $14.13(\mathrm{~F}=7.441, \mathrm{p}=0.007, \mathrm{t}=-$ 2.054, $\mathrm{df}=203.778, \mathrm{p}=0.041$ ).

For both the first and the current forms of employment, it turned out that banks whose majority shareholders are foreign investors, make use of flexible forms of employment more often than ones owned by domestic capital. This is due to the fact that all cooperative banks in Poland have majority domestic capital, whereas most of commercial banks are predominantly owned by foreign investors (The average age of an employee at banks with majority of national capital was 38.82 and at banks with majority of foreign capital $34.21(\mathrm{~F}=43.076, \mathrm{p}=0.000$, $\mathrm{t}=10.020, \mathrm{df}=1642.829, \mathrm{p}=0.000$ ). The average length of work experience with current employer at banks with majority of national capital was 11.82 , and at banks with majority of foreign capital $7.74(\mathrm{~F}=94.161, \mathrm{p}=0.000$, $\mathrm{t}=9.213, \mathrm{df}=1567.994, \mathrm{p}=0.000)$. The average length of work experience in banking at banks with majority of national capital was 14.11 and at banks with majority of foreign capital 9.85 ( $\mathrm{F}=97.386, \mathrm{p}=0.000, \mathrm{t}=9.493$, $\mathrm{df}=1599.274, \mathrm{p}=0.000$ ). The average length of total work experience at banks with majority of national capital was 17.08 and at banks with majority of foreign capital 12.621 $(\mathrm{F}=77.751, \mathrm{p}=0.000, \mathrm{t}=9.340, \mathrm{df}=1659.010$, $\mathrm{p}=0.000$ ). The average number of days absent from work in the last year (not including annual leave) at banks with majority of national capital was 10.84 and at banks with majority of foreign capital $10.05(\mathrm{~F}=1.466, \mathrm{p}=0.226$, $\mathrm{t}=0.498, \mathrm{df}=685, \mathrm{p}=0.619)$.

Women are slightly less likely than men to be employed at the beginning of their careers within the framework of flexible forms of employment. If we assume that a typical employment contract for an indefinite period is the safest and most desirable form of employment, it undermines the argument of discrimination against women at the workplace. Simultaneously, the gender (female) is positively associated with higher job insecurity (Ištoňová and Fedáková 2015). Muster's research confirms that Polish women choose flexible forms of employment because they allow them to combine the role of mother and employee. At the same time, they give less respect and social respect (2012). Discrimination against women in banks requires further analysis, however.

The results obtained in relation to the size of the employees' branch locality are varied. Its interpretation requires a broader analysis.

New questions arose in the next analysis of the forms of employment: is the first employment based on a particular form of employment favouring this form of employment in the future? Or is the first employment within the framework of the flexible forms of employment conducive to further employment on the same basis?

In other words, will the persons who were employed under a flexible form of employment have a real chance of subsequent employment under a contract of employment for an indefinite period? Due to the small sample size in 
the case of flexible forms of employment, and due to the lack of statistical significance in the case of fixed-term contracts, one can draw conclusions from table 11 only to a limited extent.

Table 11. Correlations of first and current forms of employment

\begin{tabular}{|c|c|c|c|c|}
\hline & Chi-squared & $\mathrm{df}$ & significance & Phi Yula \\
\hline Fixed term contract - first and current & 0.364 & 1 & 0.547 & 0.015 \\
\hline Indefinite employment contract - first and current & 13.524 & 1 & 0.000 & 0.091 \\
\hline Contract of mandate, contract for specific work - first and current & 262.462 & 1 & 0.000 & 0.401 \\
\hline Agency agreement - first and current & 521.827 & 1 & $\mathbf{0 . 0 0 0}$ & 0.565 \\
\hline Work contracting - first and current & 27.980 & 1 & 0.000 & 0.131 \\
\hline Self-employment - first and current & 480.375 & 1 & 0.000 & 0.542 \\
\hline Job sharing - first and current & 302.807 & 1 & 0.000 & 0.431 \\
\hline Probationary period contract, replacement employment contract - first and current & 39.829 & 1 & $\mathbf{0 . 0 0 0}$ & 0.156 \\
\hline On-call employment - first and current & 0.001 & 1 & 0.980 & 0.001 \\
\hline All flexible forms of employment together - first and current & 12.951 & 1 & 0.000 & 0.089 \\
\hline
\end{tabular}

Source: own computations based on the survey data.

It is important that only a small part of people who are employed at banks for the first time for an indefinite period, will further be employed under this form ( 0.091 correlation). It means that the change in the forms of employment is really possible. At the same time, it should be remembered that the elasytical forms of employment differently than in the past are also used in the case of employment of specialists (Muster 2012) and the banking sector is specific and many banks offer the possibility of developing, according to the specific promotion paths related to training (Davydenko, Kaźmierczyk, Romashkina, Żelichowska, 2017).

\section{Conclusions}

The carried out analysis allowed us to assess the popularity of flexible forms of employment in banks and compare its levels in different social groups. There are gropus of emploees or groups of banks caracterised by sporadic flexible forms of employment (senior managerial position 7.5\%; university education (major in economics) $23.9 \%$; cooperative bank $20.1 \%$; banks with majority of national capital $23.6 \%$; above 35 years old $13.7 \%$; above 7 years work experience with current employer $12.1 \%$; above 10 years work experience in banking $12.6 \%$; above 12 years total work experience $14.1 \%$ ). Moreover, the conducted study confirmed the posed thesis, namely that flexible forms of employment are more common among young people, who are at the beginning of their professional career, than among workers with seniority. This thesis has been confirmed both with regard to the employees' first and the current form of employment. It is important that flexible forms of employment are more popular among young people with less work experience at the present employer, less experience in banking and less job seniority in general.

The results of the empirical analysis also support the second thesis, which assumed that flexible forms of employment are less frequent among managerial staff. The higher a banker's position on the career ladder, the more likely he or she is to enter into the traditional employment contract for an indefinite period of time rather than one of the flexible forms of employment. This thesis has been confirmed only in relation to the current form of employment. All employees, including future managers, are more likely to enter into flexible forms of employment when at the beginning of their career.

A number of areas that require further in-depth analysis have emerged from this study. For example, females at the beginning of their professional career are slightly less likely than males to be employed in flexible forms of employment. This counters the expected argument, especially in the context of the discrimination of females on the labour market. Another area that requires further research is the influence of the size of the banks' locality on the use of flexible forms of employment. The relevant data obtained are inconclusive. 
All the empirical analysis based on sample of bank employees in Poland, thus the results could not be the same in different countries and professional groups. Moreover, bankers are only a part of the financial sector workers and react in different way to the business cycle changes. It will be interesting to study flexible forms of employment in a conditions of business crisis. It requires survey of employees in different phases of business cycles. Probably some new insights considering flexibility could be reached by analysing psychological stress and job insecurity of workers. Furthermore, the results obtained in relation to the size of the employees' branch locality requires a broader analysis. The relationship between flexible forms of organisation, shamrock organization by Ch. Handy and education level also requires confirmation by additional studies.

Banks in Poland (especially the commercial ones and banks with the majority of foreign capital) commonly make use of flexible forms of employment. In view of the above-mentioned social changes and the increasing importance of young employees [on the job market], the following questions arise: What are their expectations? Do they really want flexible forms of employment? Would they not prefer to have a stable job, which would give them the opportunity to take out a mortgage?

\section{References}

Andrzejczak, A. 2014. Społeczna odpowiedzialność uczelni za kształcenie dla rynku pracy [Social responsibility of the university for education for the labor market], in Kamiński, R. (Ed.). Wybrane problemy wspótczesnego rynku pracy [Selected problems of the modern labor market]. Poznań: Polskie Towarzystwo Ekonomiczne Oddział w Poznaniu, 63-89.

Andrzejczak, A. 2015. Dilemmas of Education for Sustainable Development, in Gorges, I. (Ed.). Global perspectives on Sustainable Regional Development. Hamburg: Verlag Dr. Kovac GMBH Hamburg, 185-211.

Anonimowe Badanie Pracowników Banków [Anonymous Bank Employees Survey], 2016 https://tinyurl.com/yaewovr9 (accessed March 7, 2018).

Bąk-Grabowska, D. and Jagoda, A. 2015. Flexibility of Workplace vs. Non-standard Employment Forms - Co-occurrence Analysis, Journal of International Studies 8(2): 130-38.

Bąk-Grabowska, D. and Jagoda, A. 2016, Non-standard forms of employment and working time exibility - the categories of cooccurrence?, Journal of International Studies 9(1): 229-239. http://doi.org/10.14254/2071-8330.2016/9-1/17

Barska, A. and Wojciech, M. 2014. Innovations of the food products from the perspective of the gen Y consumers, Acta Scientiarum Polonorum. Oeconomia 13(3): 17-27.

Bąk, E. 2009. Nietypowe Formy Zatrudnienia na Rynku Pracy [Unusual Forms of Employment on the Labor Market]. Warszawa: C.H. Beck.

Bondaryeva, I.A., Kravchenko, S.I. and Mieshkov, A.V. 2015. Features of The Investment and Innovative Orientation in Students` Training in Technical Higher Educational Institution (on the Example of Donetsk Region), Naucno-tehniceskie vedoomosti SPBGPU. Ekonomicieskie nauki [Scientific and technical lists SPBGPU. Economic sciences] 4 (223): 236-244.

Burroni, L. and Keune, M. 2011. Flexicurity: A Conceptual Critique, European Journal of Industrial Relations 17(1): 75-91.

Buschoff, K.S. and Protsch, P. 2008. (A-)typisch und (un-)sicher? Zur sozialen Sicherung von "nicht standardisierten" Arbeitsverhältnissen in Europa [(A-) typical and (un) sure? On social protection of "non-standardized" employment relationships in Europe], Internationale Revue für Soziale Sicherheit [International Social Security Review] 61 (4): 55-78. http://doi.org/10.1111/j.1752-1726.2008.00323.x

Cheese, P. 2015. Zero-hours and short-hours contracts in the UK: Employer and employee perspectives, Policy report. London: CIPD.

Cheng, G.H.L. and Chan D.K.S. 2008. Who Suffers More from Job Insecurity? A Meta-Analytic Review, Applied Psychology: An International Review 57(2): 272-303. 
The International Journal

ISSN 2345-0282 (online) http://jssidoi.org/jesi/

2018 Volume 6 Number 2 (December)

http://doi.org/10.9770/jesi.2018.6.2(21)

Contract types and employer responsibilities (n.d.). https://www.gov.uk/contract-types-and-employer-responsibilities/zero-hour-contracts (accessed March 7, 2018).

Davydenko, V.A. 2004. Model specialista s uciotom potrebnosti rynka profiesionalnogo truda [Models of specialists taking into account the needs of the market of professional labor]. Model specialista XXI vieka v kontekste modernizacii vysshego obrazovanija: Ciast 1. Materialy Vseross. nauc.-metod. konferencii 15-17 sentyabrya [Model of specialist in $20^{\text {th }}$ century in the context of modernization of higher education. Part 1. Tuapse: Materials of the All-Russian Scientific and Methodical Conference], 88-92.

Davydenko, V., Kaźmierczyk, J., Romashkina, G.F., Żelichowska, E. 2017. Diversity of employee incentives from the perspective of banks employees in Poland-empirical approach, Entrepreneurship and Sustainability Issues 5(1), 116-126, http://doi.org/10.9770/jesi.2017.5.1(9)

Dolgui, A. and Proth, J.M. 2013. Outsourcing: definitions and analysis, International Journal of Production Research 51(23-24): 67696777.

Drela, K. 2013. Zatrudnienie nietypowe [Unusual employment], Research papers of Wroctaw University of Economics 305: 129-141.

Eichhorst, W. and Kendzia, M.J. 2016. Workforce Segmentation in Germany: From the Founding Era to the Present Time, Journal of Labour Market Research 49(4): 297-315.

Eurofound 2015. New forms of employment, Publications Office of the European Union, Luxembourg. https://www.eurofound.europa.eu/sites/default/files/ef publication/field ef document/ef1461en.pdf (accessed March 7, 2018).

European Commission 2007. Towards Common Principles of Flexicurity. More and better jobs through flexibility and security. Belgium: Directorate-General for Employment, Social Affairs and Equal Opportunities Unit D.2.

Garbat, M. 2018. Wspieranie zatrudnienia osób z niepełnosprawnościami w świetle koncepcji Artura Pigou i Ronalda Coase [Supporting the employment of people with disabilities in the light of the concepts of Artur Pigou and Ronald Coase], Zeszyty Naukowe Polskiego Towrzysta Ekonomicznego w Zielonej Górze [Scientific Journal of the Polish Economic Association in Zielona Góra] 8: 31-55. https://doi.org/10.26366/PTE.ZG.2018.122

Grzeszczyk, E. 2003. Młodzi ludzie kariery jako środowisko wzorcotwórcze [Young people's career as an pattern-creating environment], in Jawłowska, A. and Woroniecka, G. (Ed.). Kultura w procesie zmiany. Z badań nad kultura w Polsce lat dziewięćdziesiatych [Culture in the process of change. From research on culture in Poland in the nineties]. Olsztyn: Wydawnictwo Uniwersytetu Warmińsko-Mazurskiego, 68-91.

Handy, Ch. 2014. The Shamrock Organisation, Business Strategy Review 25(4): 8.

Heyes, J. 2011. Flexicurity, employment protection and the jobs crisis, Work, Employment and Society 25(4): 642-657.

International Labour Office 2016. Non-Standard Employment Around The World. Understanding challenges, shaping prospects. Geneva. http://www.ilo.org/wcmsp5/groups/public/---dgreports/---dcomm/---publ/documents/publication/wcms_534326.pdf

(accessed March 7, 2018)

Ištoňová, L. and Fedáková, D. 2015. Predictors and Consequences of Job Insecurity: Comparison of Slovakia and Estonia, Studies of Transition States and Societies 7(3): 21-37.

Jahn, E.J., Riphahn, R.T. and Schnabel, C. 2012. Feature: flexible forms of employment: boon and bane, The Economic Journal 122: F115F124.

Jasarevic, C. 2012. Fleksibilizacija rada - reshenie ili zabluda [Flexibilization is a solution - a solution or a delusion]. Proceedings of Novi Sad Faculty of Law, 1: 173-192.

Kalinowska, B. 2008. Elastyczne formy zatrudnienia i organizacji pracy w przedsiębiorstwie [Flexible forms of employment and work organization in an enterprise], in Jarmołowicz, W. (Ed.). Gospodarowanie pracq we wspótczesnym przedsiębiorstwie [Managing work in a modern enterprise]. Poznań: Wydawnictwo Forum Naukowe, 193-206. 
Kalinowska, I., Kujszczyk, B., Mańturz, M. and Świercz, B. 2014. Elastyczne formy zatrudnienia [Flexible forms of employment]. Informator. Warszawa: Wojewódzki Urząd Pracy w Warszawie.

Kaźmierczyk, J. 2015. Human capital development in Polish banks, Baltic Rim Economies 3, 37.

Krukowski, K. and Oliński, M. 2010. Flexicurity w teorii i praktyce [Flexicurity in theory and practice]. Olsztyn: Fundacja Wspieranie i Promocja Przedsiębiorczości na Warmii i Mazurach.

Muster, R. 2012. Elastyczne formy pracy w opiniach pracowników nieetatowych [Flexible forms of work in the opinions of non-permanent employees], Opuscula Sociologica 1: 17-29.

OECD 2013. OECD Employment Outlook. Paris.

Paszkowicz, M.A. 2009. Kompetencje a oczekiwania współczesnych organizacji [Competences and expectations of contemporary organizations], Zeszyty Naukowe Politechniki Poznańskiej, Organizacja i Zarządzanie [Scientific Journal of Poznan University of Technology, Organization and Management] 54: 79-98.

Pfeifer, Ch. 2005. Flexibility, Dual Labour Markets, and Temporary Employment. Empirical Evidence from German Establishment Data, Management Revue 1: 404-422.

Romashkina, G.F. and Andrianova, E.V. 2007. Motivaciya v sfere truda: idealnye modeli i poviedenie [Motivation in the sphere of work: ideal models and behaviors], Izvestija Uralskogo federalnogo universiteta. Serija 3. Obsciestvennye nauki [News of Ural Federal University. Series 3. Social Sciences] 51(3): 50-55.

Salikova, N.M. 2012. Gibkie i netipicnye formy zanyatosti: neobhodimost i celesoobraznost [Flexible and atypical forms of employment: the need and feasibility], Russian Juridical Journal 1: 176-182.

Schmidt, J. 2011. Charakterystyka zatrudnionych i specyfika zatrudniania w organizacjach pozarządowych [Characteristics of the employed and the specifics of employment in non-governmental organizations], in Przybylska-Kapuścińska, W. (Ed.). Gospodarka. Technologia. Kapitat społeczny [Economy. Technology. Social capital]. Poznań: Wyd. UEP, 232-245.

Shelest, O. 2015. Risk of Investments in Human Capital and Expected Worker Mobility, International Journal of Management and Economics 47: 82-106.

Shelest, O. 2016. Inwestowanie w szkolenia - ryzyko pracownika? [Investing in training - employee risk?], Zarzadzanie Zasobami Ludzkimi [Human Resource Management] 1(108): 25-40.

Soniewicki, M. 2015. The company's international competitive advantage - the role of knowledge. Warsaw: Difin.

Storey, J., Quintas, P., Taylor, P. and Fowle, W. 2002. Flexible employment contracts and their implications for product and process innovation, The International Journal of Human Resource Management 13(1): 1-18.

Süß, S. and Kleiner, M. 2007. The Psychological Relationship between Companies and Freelancers. An Empirical Study of the Commitment and the Work-related Expectations of Freelancers, Management Revue September, 251-270.

Twaronite, K. 2015. Global generations, a global study on work-life challenges across generation. http://www.ey.media.pl/pr/297876 (accessed March 7, 2018).

Vanhercke, D., Peeters, E., De Cuyper, N. and De Witte, H. 2014. Defining perceived employability: a psychological approach, Personnel Review 43(4): 592-605.

Voronov, V., Lavrinenko, O.J. and Stashane, J.V. 2014. Ocenka dynamiki mezregionalnyh razliciy (Evropejskim opyt) [Assessment of the dynamics of interregional differences (European experience)], Sociologicieskie issledovaniya [Sociological research] 1: 29-39.

Wilthagen, T. 1998. Flexicurity: A New Paradigm for Labour Market Policy Reform?, WZB, Discussion paper FSI 98-202: 1-34.

Węgrzyn, G. 2009. Ciemna strona telepracy [Dark side of telework], in Partycki, S. (Ed.). E-gospodarka, e-społeczeństwo w Europie Środkowej $i$ Wschodniej [E-economy, e-society in Central and Eastern Europe]. Lublin: Wydawnictwo KUL, 58-61. 
The International Journal

ENTREPRENEURSHIP AND SUSTAINABILITY ISSUES

ISSN 2345-0282 (online) http://jssidoi.org/jesi/

2018 Volume 6 Number 2 (December)

http://doi.org/10.9770/jesi.2018.6.2(21)

Wyrwa, J. and Piątyszek-Pych, A. 2012. Bezpieczny i elastyczny rynek pracy w Europie - idea koncepcji flexicurity [A safe and flexible labor market in Europe - the idea of flexicurity concept], Problemy Profesjologii [Problems of Professorism] 1: 33-57.

Zielona Linia 2011. Raport z wyników ankiety "Elastyczne formy zatrudnienia" [Report on the results of the survey "Flexible forms of employment"], Centrum Integracyjno-Konsultacyjne Służb Zatrudnienia [Integration and Consulting Center for Employment Services]: 117.

\section{Aknowledgements}

The study was sponsored by RGNF (Russian Humanitarian Science Foundation). Project: "Capabilities and restrictions of new industrialization and contradictions of sociocultural space: on Tyumen region example", No. 16-03-00500. Tyumen State University.

Jerzy KAŹMIERCZYK $(\mathrm{PhD})$ is Assistant Professor at Poznan University of Economics and Business, and Postdoc at Tyumen State University, Member of the Research Council of Polish Economic Society, Member of the Presidium and Board of Polish Economic Society Zielona Gora and Member of the Regional Labour Market Board at Lubuskie Marshal's Office. He is currently editing an issue of Scientific Journal of Polish Economic Society in Zielona Gora. Research interests: labour market, HRM, banking, macroeconomics.

ORCID ID: orcid.org/0000-0002-5976-0210

Aleksandra CHINALSKA is a graduate of Poznan University of Economics and Business and practitioner of HRM in banking. Research interests: Human Resources Management, labour market, accounting.

ORCID ID: 0000-0001-6491-0036

Register for an ORCID ID:

https://orcid.org/register

Copyright (C) 2018 by author(s) and VsI Entrepreneurship and Sustainability Center

This work is licensed under the Creative Commons Attribution International License (CC BY).

http://creativecommons.org/licenses/by/4.0/

(c) (i) Open Access 